\title{
Evaluation of Resistance of Fluoroelastomer to Ozone in Water
}

Satoshi MIWA ${ }^{1 *}, 2$, Yoshito OHTAKE ${ }^{1}$, Keiji TANAKA ${ }^{2,3 *}\left({ }^{1}\right.$ Chemicals Evaluation and Research Institute, Japan, 1600, Shimo-takano, Sugito-machi, Kitakatsushika-gun, Saitama 345-0043, Japan ${ }^{2}$ Department of Automotive Science, Graduate School of Integrated Frontier Sciences, Kyushu University 744, Motooka, Nishi-ku, Fukuoka 819-0395, Japan ${ }^{3}$ Department of Applied Chemistry, Kyushu University, 744 Motooka, Nishi-ku, Fukuoka 819-0395, Japan) *miwa-satoshi@ceri.jp and k-tanaka@cstf.kyushu-u.ac.jp

Ozone resistance of poly(vinylidene fluoride-co-hexafluoropropylene-co-tetrafluoroethylene) (poly (VDF/HFP/TFE)) cross-linked by peroxide was examined in water. Although the poly(VDF/HFP/TFE)surface was not macroscopically damaged after the ozone treatment in water, physical properties at the surface were altered. Fourier-transform infrared spectroscopy with an attenuated total reflection mode (FT-IR ATR) revealed that the ozone treatment in water decreased the number density of the triallyl isocyanurate moiety, corresponding to the cross-linking point, of poly (VDF/HFP/TFE) elastomer in the vicinity of the surface. Finally, a correlation between the changes in primary structure and physical properties at the surface is discussed to give a better understanding of the ozone treatment to cross-linked poly (VDF/HFP/TFE) in water.

(Received on October 14, 2011)

(Accepted on December 6, 2011)

Key Words : Ozone, Water, Fluoroelastomer, Cross-linking, Force-distance Curve, Fourier-transform Infrared Spectroscopy

1. 緒

言

近年，環境への負荷低減，省設備化に有利な水処理法と して，オゾンの導入が活発に行われている ${ }^{1-5)}$.オゾンは それ自身が高い酸化力を有することに加え, 水中に溶解す ると自己分解反応を生じ，その過程でヒドロキシルラジカ ル $(・ \mathrm{OH})$ 等の，オゾンより高い酸化力を有する活性酸 素種を生成する ${ }^{6-10)}$. 特に・ OH の標準酸化還元電位は $2.81 \mathrm{~V}$ と非常に高く，オゾンと直接反応しにくい飽和脂肪 族炭化水素等に対しても速やかに反応する ${ }^{11-14)}$.この才 ゾン自己分解反応を利用した促進酸化処理法が，水中に溶 存した医薬品，農薬等の難分解性物質の除去方法として高 い効果を発揮している ${ }^{15,16)}$.

一方で水中に扔けるオゾンの高い反応性のため, 空気中 で耐オゾン性を有するゴム材料が，オゾン水中では劣化す る場合がある，エチレンプロピレンジエンゴム（EPDM）

\footnotetext{
1 一般財団法人化学物質評価研究機構 高分子技術部

( 345-0043 埼玉県北葛飾郡杉戸町下高野 1600 番地)

2 九州大学大学院 統合新領域学府 オートモーティブサイエンス 専攻

3 九州大学大学院 工学研究院 応用化学部門

( ₹ 819-0395 福岡市西区元岡 744 番地)
}

は主鎖に不飽和炭化水素結合を持たないため,ゴムの一般 的なオゾン劣化現象である亀裂が発生しない ${ }^{17)}$. しかし ながら，オゾン水中では表面近傍に存在する主鎖の分解に 伴う粘着力上昇や，水相への分解物の溶出等が観測された 18-20). したがって，オゾン水使用環境にゴム製品を導入 する際は，EPDMや主鎖構造の類似したオレフィン系エ ラストマーより耐久性の高いゴム材料を使用する必要があ る.

そこで, 著者らは耐オゾン性に優れ, 数多くのゴム種の 中でも化学安定性の最も高いフッ素ゴム (FKM) に着目 している.しかしながら，オゾン水中に扔けるFKMのキ ヤラクタリゼーションに関する報告は皆無であり，このた め, オゾン水中に扔ける FKM の耐久性も検討されていな い.

FKMには主鎖構造の異なる様々な種類が存在するが, ポリ（フッ化ビニリデン（VDF）－ヘキサフルオロプロ ピレン（HFP） -テトラフルオロエチレン (TFE) ) (poly (VDF/HFP/TFE) ) 等のVDF系FKMが沉用的に 用いられる ${ }^{21)}$. 本研究ではオゾン水中に扔ける過酸化物 架橋 poly（VDF/HFP/TFE）の耐久性について検討する ことを目的として, オゾン水処理した過酸化物架橋 poly (VDF/HFP/TFE) の構造及び物性変化を行った。 


\section{2. 実験}

\section{1 試料}

Table 1 は本研究に使用した試料（FKM-a）の配合表で ある. poly（VDF/HFP/TFE）はSolvay Solexis 製 Tecnoflon P757 (フッ素含有量 $67 \mathrm{wt} \%, \mathrm{ML}_{1+10}(394 \mathrm{~K})=$ 44）を用いた。 ${ }^{19} \mathrm{~F}$ 核磁気共鳴（NMR）測定 ${ }^{22)}$ に基づき 評価したpoly（VDF/HFP/TFE）のモノマー組成比 (mol\%) は69:19:12であった. FKM-aの成形は過酸化物架 橋により行った。一般的な VDF 系FKMの架橋法（ポリ アミン，ポリオール）で作製した場合，水中の使用時にお いて受酸剂の潮解性が問題となる可能性がある ${ }^{23)}$ 。一方, 過酸化物架橋法では受酸剤を使用しないため，耐水性に及 ぼす影響は小さい。架橋剤には，2,5-ジメチル-2,5-ジ（tertブチルペルオキシ）へキサンを，共架橋剤にはトリアリル イソシアヌレート（TAIC）を使用した。8インチオープ ンロールにより混練りして得られた未架橋ゴムを $443 \mathrm{~K} \times$ 5 分間プレス成形し，厚さ約 $1 \mathrm{~mm}$ の架橋ゴムシートを作 製した。その後，熱老化処理槽内で $503 \mathrm{~K} \times 4$ 時間の二次 架橋を行い， $313 \mathrm{~K} \times 48$ 時間，減圧下で乾燥した。架橋ゴ ムシートは $20 \times 20 \times 1 \mathrm{~mm}^{3}$ の平板に切り抜き，本実験の 試料とした。Figure 1 は作製した試料の poly $(\mathrm{VDF} / \mathrm{HFP} / \mathrm{TFE})$ 主鎖と TAIC由来（成形時に生成する と考えられる架橋点，及びTAIC 同士の重合体）の化学構 造である。

Table 1 Formulation of the rubber compound FKM-a.

\begin{tabular}{lc}
\hline \multicolumn{1}{c}{ ingredients } & amount / phr \\
\hline polymer & 100 \\
2,5-dimethyl-2,5-di (tert-butylperoxy) hexane & 3.75 \\
triallyl isocyanurate (TAIC) & 2 \\
\hline
\end{tabular}

$$
\left[-\mathrm{CF}_{2}-\mathrm{CH}_{2}-1-\mathrm{CF}_{2}-\underset{\mathrm{CF}_{3}}{\mathrm{CF}}-/-\mathrm{CF}_{2}-\mathrm{CF}_{2}-\right]_{n}
$$

poly(VDF/HFP/TFE)

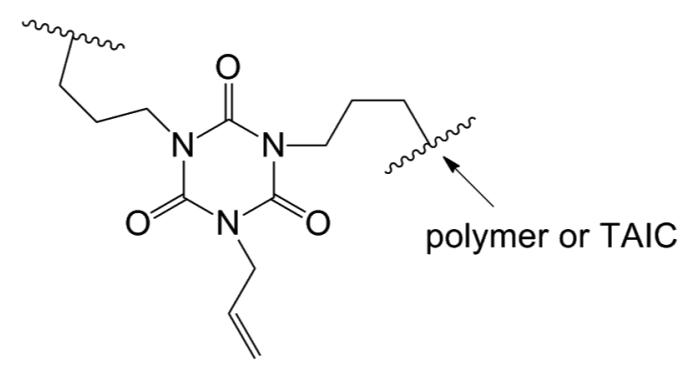

\section{Cross-linking site and polymeric TAIC}

Figure 1 Chemical structures of main chain, cross-linking site and polymeric TAIC in FKM-a.

\section{2 オゾン水処理条件}

Figure 2 はFKM-aのオゾン水処理に用いた装置の模式 図である。オゾン水処理槽は，水量 1.01 , 水温 $293 \mathrm{~K} に$ 設 定し，800回転/分で覺拌，混合した。容器内の水中飽和 溶存オゾン濃度は, FKM-a 未処理時の場合, $5.5 \mathrm{mg} \mathrm{l}^{-1}$ で あった.オゾン水処理後の試料はイオン交換水で洗浄後, $313 \mathrm{~K} \times 24$ 時間で減圧乾燥させ，各評価に供した。

\section{3 評価}

${ }^{19}$ F NMR 測定は日本電子製 JNM-ECX400を用い，観測 周波数は $376 \mathrm{MHz}$ とした。溶媒には重水素化アセトンを 用いた。走査型電子顕微鏡 (SEM) 観察は日本電子製 JSM-5610を用い，加速電圧 $10 \mathrm{kV}, 2000$ 倍の条件で行っ た。試料表面の粘着力は, 直径 $4.8 \mathrm{~mm}$ のステンレス （SUS304）製円筒プローブを $1 \mathrm{~N}$ の荷重で試料表面に 30 秒 間接触させた後，鉛直上向きに剥離させた際の荷重を接触 面積で除することで求めた。測定にはTAインスッルメン ツ製RSA-IIIを用いた。剥離速度は $1 \mathrm{~mm} \mathrm{~min}^{-1}$ とした。 試料表面の弾性率はアサイラムテクノロジー製走査型プロ ーブ顕微鏡（SPM, MFP-3D-SA-J+SRC2）を用い評価した。 曲率半径約 $7 \mathrm{~nm}$ のオリンパス製シリコン探針を用いフォ ースディスタンスカーブ測定を行った。 カンチレバーのバ 六定数（k) は $9 \mathrm{~N} \mathrm{~m}^{-1}$ であった. また，カンチレバーの押 し込み，及び引き離し速度は $100 \mathrm{~nm} \mathrm{~s}^{-1}$ とした。試料表面 のヤング率 $\left(E_{\mathrm{sur}}\right)$ (弾性率) は，フォースディスタンス カーブにHertzモデルを適用することで求めた ${ }^{24,25)}$.

$$
z-z_{0}=d-d_{0}+\sqrt{\frac{k\left(d-d_{0}\right)}{\frac{\pi}{2} E_{\text {sur }}\left(1-v_{1}{ }^{2}\right) \tan \alpha}}
$$

ここで， $z$ はピエゾスキャナーの押し込み深さ， $z_{0}$ は試料 に接触した位置のピエゾ高さ， $d, d_{0}$ はピエゾが $z, z_{0}$ 位置 におけるカンチレバーのたわみ， $v_{1}$ は試料のポアソン比 (0.5として計算)， $\alpha$ は探針先端の $1 / 2$ 角度 $\left(17.5^{\circ}\right)$ であ る. $E_{\text {sur }}$ は押し达み時から深さ $100 \mathrm{~nm}$ 程度の範囲で算出 した。フーリエ変換赤外分光（FT-IR）測定は，全反射法

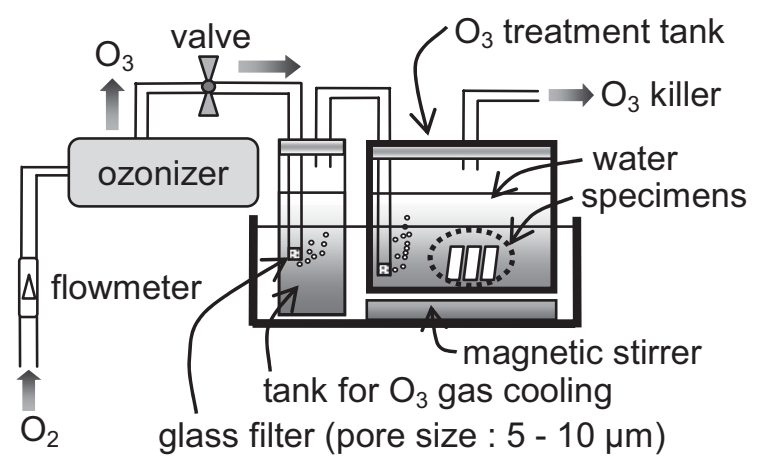

Figure 2 Schematic representation of the experimental set-up for ozone treatment in water. 
(ATR)，顕微透過法ともにバイオ・ラッドラボラトリー ズ製FTS-6000及びUMA-500により行った．ATR法のプ リズムにはゲルマニウム結晶（入射角度 $30^{\circ}$ ）を用いた。 水中の全有機炭素（TOC）測定は島津製作所製 TOC-V $\mathrm{CPH} / \mathrm{CPN}$ analyzerにより行った. サイズ排除クロマトグ ラフ（SEC）測定は，カラムに昭和電工製 Shodex KF$806 \mathrm{M}$ を 2 本連結し, 溶離液に微量のジブチルヒドロキシ トルエンを溶解したテトラヒドロフラン（THF）を用い た。送液ポンプは日本分光製PU-980, 示差屈折計は昭和 電工製 Shodex RI-101を用いた。

\section{3. 結 果と考察}

\section{1 オゾン水処理による FKM-a の外観及び表面物性変化}

オゾン水処理したEPDMは，表面近傍の分子鎖が酸化， 分解するため，表面粘着力が著しく上昇する ${ }^{18)}$ 。ここで も同様に，オゾン水処理後 FKM-a 表面の粘着力を評価し た. Figure 3 はFKM-a表面の粘着力とオゾン水処理時間 の関係である。比較のため，図には既報の EPDM表面の 粘着力変化も示している. FKM-a 表面の粘着力は処理時 間の経過とともに徐々に上昇し， $1.8 \times 10^{5} \mathrm{~Pa}$ でほぼ定 となった．粘着力の上昇は, EPDM と比較して小さいが, FKM-a 表面がオゾン水処理によって変性したことを意味 している。一方で，FKM-aはEPDMよりも長期間処理し たにも関わらず，試料表面に粘着力を発生させるような液 状物質は観察されなかった。そこで，オゾン水処理後 FKM-a 表面の形態を更に調査するため，SEM 観察を行っ た。

Figure 4 は未処理及び56日間オゾン水処理を行った FKM-a 表面のSEM 像である.オゾン水処理後の FKM-a 表面は亀裂等もなく平滑であり，処理前後でその形態に有 意差は認められなかった. したがって，オゾン水処理によ る FKM-a 表面の粘着力上昇は, EPDMで認められたよう な液状物質の発生等, マクロな形態変化に起因するもので はないと考えられる。

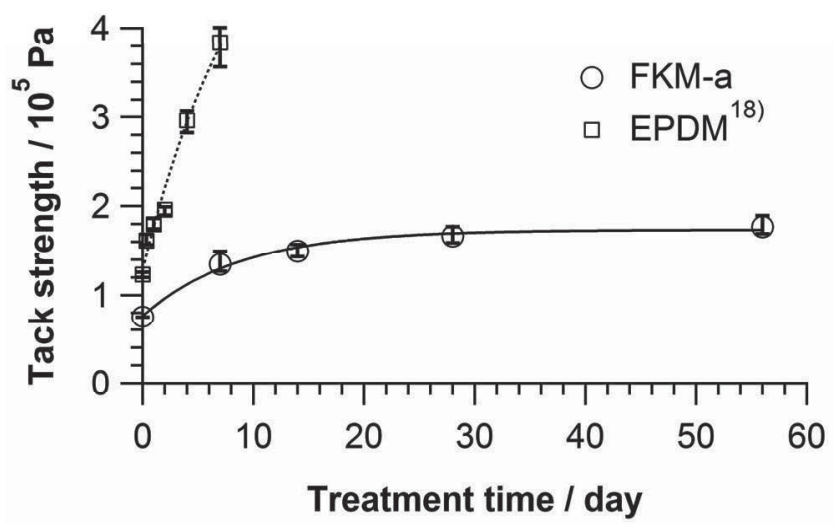

Figure 3 Tack strength of FKM-a and EPDM ${ }^{18)}$ as a function of ozone treatment time.
オゾン水処理に伴う FKM-a 表面の更なる物性変化を検 討した. Figure 5 は（a）未処理及び（b）56日間オゾン 水処理後における FKM-a 表面のフォースディスタンスカ ーブである，黑及びグレーの実線はそれぞれ，押し込み及 び引き離しに対応する，また，水平に示した破線より上方 は斥力, 下方は引力領域を示している. 両試料表面の押し 込みカーブを比較したところ，オゾン水処理後の傾きの方 が小さかった. 古典的な Hertz弾性理論に基づき表面領域 におけるヤング率 $\left(E_{\mathrm{sur}}\right)$ を算出し, オゾン水処理時間と の関係をプロットした. Figure 6 上段はその結果である. 処理時間の経過とともにFKM-aの $E_{\mathrm{sur}}$ は減少した。また， オゾン水処理前後のフォースディスタンスカーブ形状に差 異が認められ, 特にオゾン水処理後 FKM-a 表面の引き離 し時の斥力低下が，未処理表面に比べて速い.オゾン水処
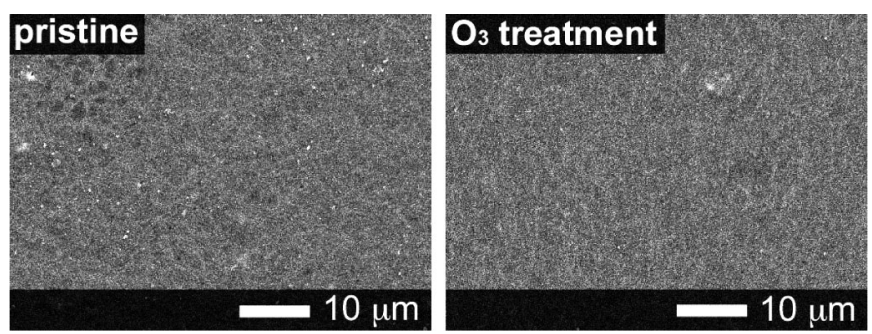

Figure 4 SEM images of FKM-a surface.

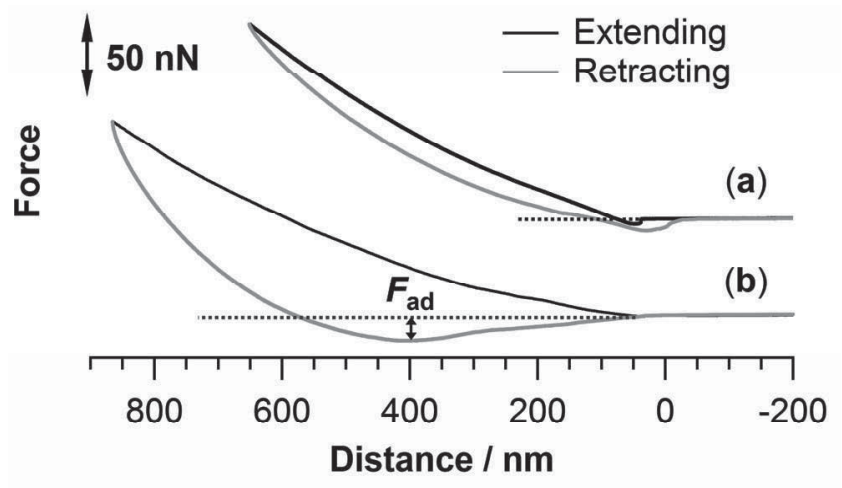

Figure 5 Force-distance curves of (a) pristine FKM-a and (b) FKM-a after ozone treatment in water for 56 days.

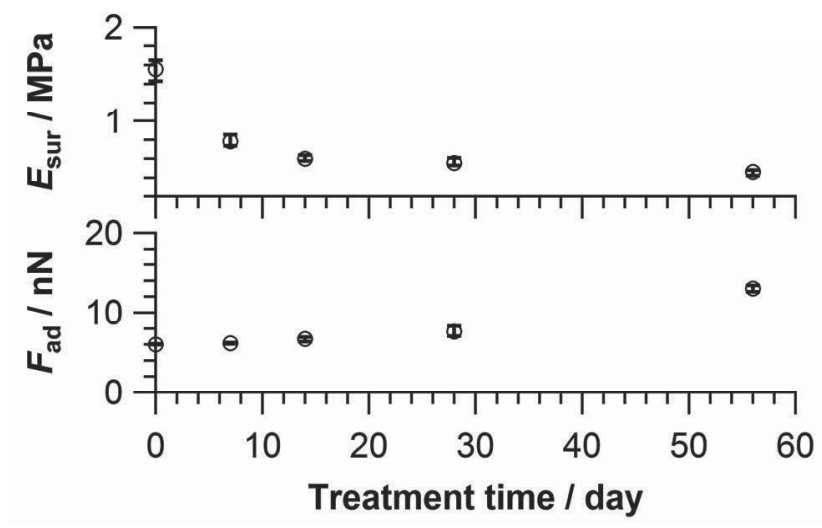

Figure 6 Plots of $E_{\text {sur }}$ and $F_{\text {ad }}$ of FKM-a, calculated by force-distance curves, versus ozone treatment time. 
理後表面は，ゴム架橋密度等の変化に伴い，緩和速度や凝 着力変化が寄与している可能性がある. 引き離し過程にお ける最大引力，すなわち，凝着力 $\left(F_{\mathrm{ad}}\right)$ はオゾン水処理 後の方が大きかった. Figure 6 下段は凝着力とオゾン水処 理時間との関係である. FKM-a 表面の $F_{\mathrm{ad}}$ は処理時間の経 過とともに上昇する傾向が認められた。以上の結果から， オゾン水処理はFKM-a 表面のマクロな構造変化は誘起し ないが，表面近傍の物性を変化させると結論できる。した がって，オゾン水処理は試料表面近傍における FKM-aの 分子レベルの構造に影響を与えると予想できる.

\section{2 オゾン水処理による FKM-a の一次構造変化}

Figure 7 は（a）未処理，（b）7日間処理後，（c）56日 間処理後の FKM-aのATR FT-IRスペクトルである．各ス ペクトルは酸素や熱に対して安定な $1350 \mathrm{~cm}^{-1}$ の $\mathrm{CF}_{3}$ 伸縮 振動の吸収ピークを内部標準として規格化した ${ }^{26)}$. 未処 理の FKM-aのスペクトルには poly（VDF/HFP/TFE）鎖 に起因する吸収ピークに加え ${ }^{26-28)} ， 1690$ 及び $1455 \mathrm{~cm}^{-1}$ に TAICのイソシアヌレート $(\mathrm{N}-\mathrm{C}=\mathrm{O})$ 基に帰属される 吸収ピークが観測された ${ }^{29)}$ 。 Table 2 は poly （VDF/HFP/TFE）に起因する主な吸収ピークを示してい る. FKM-aの ATR FT-IRスペクトルは，オゾン水処理時 間の経過とともに変化した。オゾン水処理後は 3500 ～ $3000 \mathrm{~cm}^{-1}$ 付近の $\mathrm{OH}$ 伸縮振動に帰属される幅広い吸収ピ ークが発達し，1690及び $1455 \mathrm{~cm}^{-1}$ の TAICのイソシアヌ レート基の吸収ピークは減衰した。

FKM-aに架橋点として存在するTAICのモデル化合物 として TAIC 重合体を調製し，オゾン水処理した際の構造 変化，並びに水中の TOCの変化を調べた，TAIC 重合体 は水に不溶であるため, 乳鉢で粉砕した粉末状の TAIC重 合体をオゾン水中に擋拌する不均一系で実験を行った。 Figure 8 は（a）未処理及び（b）4日間オゾン水処理を施
したTAIC 重合体の透過FT-IR スペクトルである。スペク トルは $1690 \mathrm{~cm}^{-1}$ の $\mathrm{N}-\mathrm{C}=\mathrm{O}$ に帰属される吸収ピークを内部 標準として規格化した。オゾン水処理後には，-OH由来の 幅広い吸収ピークが $3400 \mathrm{~cm}^{-1}$ 付近に観測された。また， $1100 \sim 1000 \mathrm{~cm}^{-1}$ 付近に C-O (-H) 結合由来と推察される吸 収ピーク強度が上昇した。一方，アルキル基に帰属される 3000 ～ $2800 \mathrm{~cm}^{-1}$ の吸収ピーク強度は若干減少した。これ

Table 2 Band positions and their assignments in the ATR FTIR spectrum of FKM-a.

\begin{tabular}{ll}
\hline \multicolumn{1}{c}{ wavenumber $/ \mathrm{cm}^{-1}$} & \multicolumn{1}{c}{ vibration mode ${ }^{*}$} \\
\hline 3030 & $v\left(\mathrm{CH}_{2}\right)$ \\
2990 & $v\left(\mathrm{CH}_{2}\right)$ \\
1690 & $v(\mathrm{C}=\mathrm{O})$ \\
1455 & $\delta\left(\mathrm{CH}_{2}\right)$ \\
1430 & $\delta\left(\mathrm{CH}_{2}\right)$ \\
1395 & $\omega\left(\mathrm{CH}_{2}\right), v(\mathrm{CC}), v(\mathrm{CF})$ \\
1350 & $v\left(\mathrm{CF}_{3}\right)$ \\
1280 & $v\left(\mathrm{CF}_{2}\right), v(\mathrm{CC}), \delta(\mathrm{CCC})$ \\
$1200-1100$ & $v\left(\mathrm{CF}_{2}\right), \mathrm{r}(\mathrm{CF})_{2}, \mathrm{r}\left(\mathrm{CH}_{2}\right)$ \\
885 & $v\left(\mathrm{CF}_{2}\right), v(\mathrm{CC})$ \\
\hline
\end{tabular}

${ }^{*} v$; stretching, $\delta$; bending, $\omega$; wagging, r; rocking.

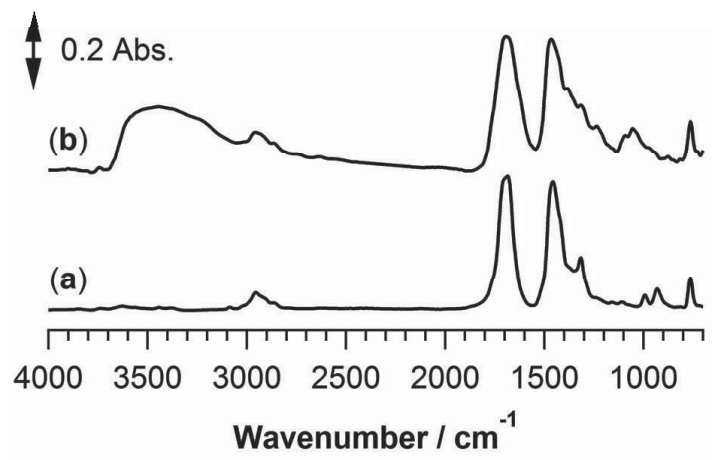

Figure 8 FT-IR spectra of (a) polymeric TAIC and (b) that after ozone treatment in water for 4 days.

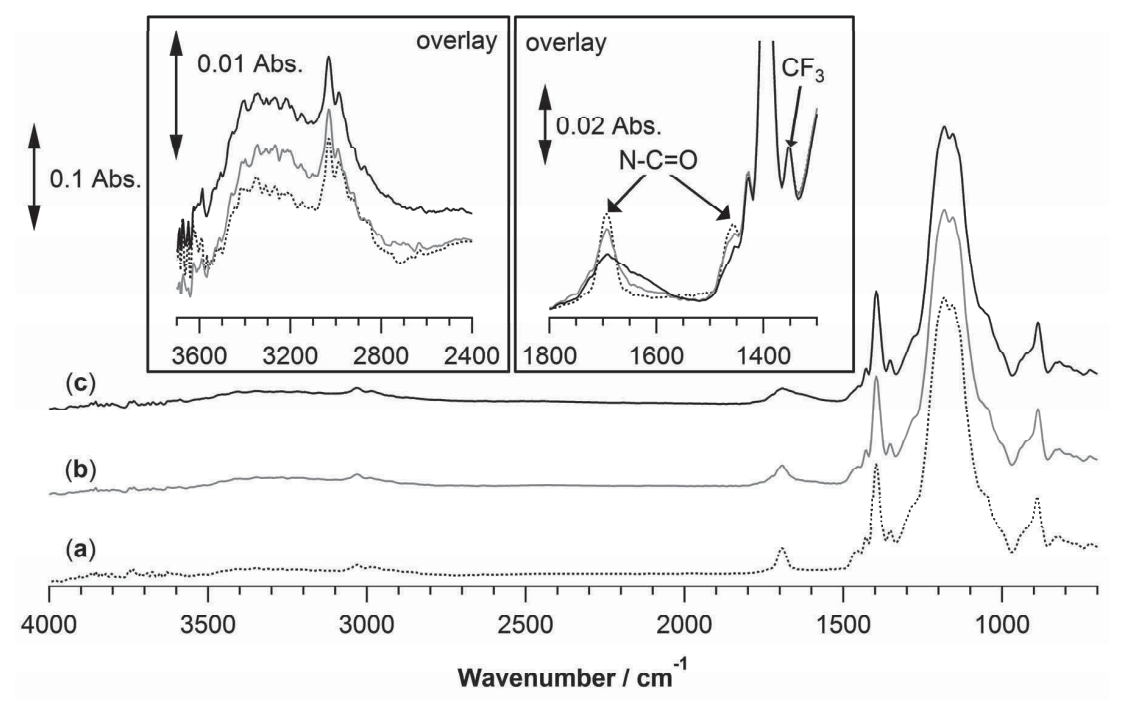

Figure 7 ATR FT-IR spectra of (a) pristine FKM-a and FKM-a after ozone treatment in water for (b) 7 days, and (c) 56 days. 
らの結果は, TAIC 重合体がオゾン水中で劣化することを 示している，そこで，劣化物が水中へ溶出しているか確認 するため, 水中の TOCを測定した.オゾン水中に $200 \mathrm{mg} \mathrm{l}^{-1}$ の TAIC 重合体を分散，擋拌した状態で96時間処理した結 果，水中の TOCは 1 日後に $6 \mathrm{mg} \mathrm{l}^{-1} ， 4$ 日後には $26 \mathrm{mg} \mathrm{l}^{-1}$ へ と増加した。この結果は上記予測と矛盾しない。以上の結 果を総合すると，オゾン水処理されたFKM-a 表面近傍で は，TAIC由来のアルキル部位が優先的に酸化し，その反 応過程で分解した一部の成分が，水中へ溶出すると考えら れる。

オゾン水処理により TAIC由来部位が劣化する一方で, poly（VDF/HFP/TFE）主鎖の劣化は観測されていない. オゾン水処理に伴う poly（VDF/HFP/TFE）主鎖の切断 を検討するため，分子量測定を行った。 Figure 9 はSEC 測定により評価した（a）未処理及び（b）56日間オゾン 水処理後における poly（VDF/HFP/TFE）の分子量分布 曲線である。オゾン水処理前後で両試料の SEC 曲線には 変化が観測されなかったことから, 主鎖部は酸素, オゾン, 高熱等に対する耐久性と同様に，オゾン水中でも高い安定 性を有することが示唆された。

\section{3 オゾン水処理に伴う FKM-aの劣化要因に関する考察}

FT-IR，TOC及びSEC 測定の結果より，オゾン水処理 による FKM-a の表面物性変化は, poly（VDF/HFP/TFE） 主鎖部でなく，TAIC由来部位の劣化によって引き起こさ れると結論できる。TAIC由来部位の劣化は，FKM-a表 面近傍の架橋点の減少に対応する。古典ゴム弾性理論によ れば，弾性率は有効網目鎖密度に比例することから ${ }^{30)}$ ， Figure 6 で観測されたFKM-aにおける $E_{\text {sur }}$ の低下と，表 面近傍の架橋点減少が同時に進む関係は矛盾しない.また, オゾン水処理後にFKM-aの架橋点が減少すれば，膨潤度 は変化すると予想される。このため，FKM-aのアセトン に対する膨潤度を評価した. Figure 10 はFKM-aのアセト ンに対する膨潤度とオゾン水処理時間の関係である。ここ で，膨潤度は膨潤状態と乾燥状態の重量比で定義した。才

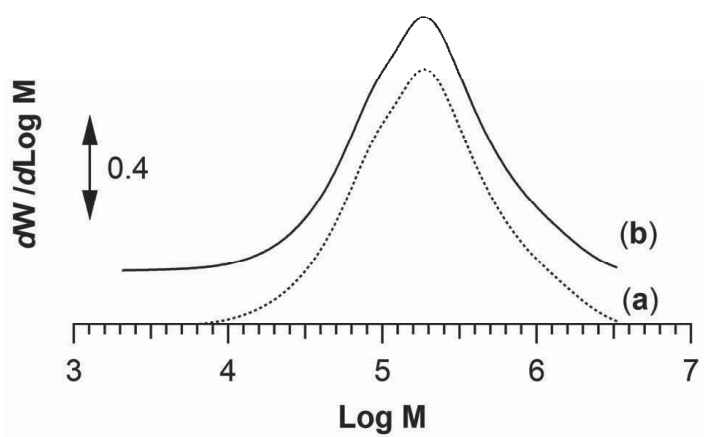

Figure 9 Molecular weight distribution curves of (a) pristine/native poly (VDF/HFP/TFE) film and (b) that after ozone treatment in water for 56 days.

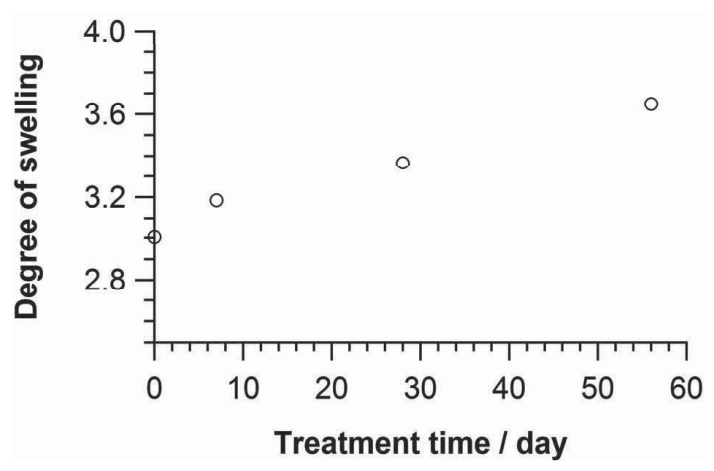

Figure 10 Relationship between degree of swelling of FKM-a and ozone treatment time.

ゾン水処理時間の増加に伴い, FKM-aの膨潤度は増加し た.したがって，Figure 10の結果より，オゾン水処理に 伴いFKM-aの架橋密度は減少すると結論できる.

\section{4. 結 論}

過酸化物架橋 poly（VDF/HFP/TFE）にオゾン水処理 を施してもマクロな劣化は起こらないことが確認された. これは，主鎖部のC-F 結合がオゾン水中でも極めて安定で あることに起因する。また, poly（VDF/HFP/TFE）に おいて-CH $2_{2}$ の隣には- $\mathrm{CF}_{2}$-又は-CF $\left(\mathrm{CF}_{3}\right)$-が結合しやすい ことも分かっている.このような一次構造では, C-H結合 が電気陰性度の高い $\mathrm{F}$ 原子によってオゾンや・OHから遮 蔽されていることもその安定性の要因である。しかしなが ら，架橋点を形成する TAIC 由来のアルキル部位はオゾン 水中で容易に酸化し，分解する。 その結果，表面近傍の力 学物性が変化する。したがって，オゾン水中で全く劣化を 示さないゴム材料の設計・構築には, 主鎖骨格だけでなく, 架橋部位の選択も重要となる.今後は，主鎖や架橋法の改 良による安定な架橋点形成や，表面改質による架橋部保護 等の技術も検討する必要がある。

\section{謝辞}

本研究の一部は文部科学省のナノテクノロジーネットワ ークプロジェクト（九州地区ナノテクノロジー拠点ネット ワーク）の支援を受けて実施しました。

\section{References}

1 ) Somiya, I.: "Ozone Handbook" , Nippon Ozone Kyokai Ed., Sanyu Shobou, Yokohama, Chapter 1 (2004)

2 ) Nishimura, Y.; Kanaya, T.; Ohkubo, N.; Okada, K.; Hanada, K.: Nippon Shokuhin Kogakukaishi, 2, 103 (2001)

3 ) Sugimitsu, H.: “Ozone no Kiso to Ouyou” , Kourin, Tokyo, Chapter 9 (1996)

4 ) Camel, V.; Bermond, A.: Water Res., 32, 3208 (1998)

5 ) von Gunten, U.; Water Res., 37, 1469 (2003)

6 ) Staehelin, J.; Hoigné, J.: Environ. Sci. Tech., 16, 676 (1982)

7 ) Staehelin, J.; Bühler R. E.; Hoigné, J.: J. Phys. Chem., 88, 5999 (1984)

8 ) Bühler, R. E.; Staehelin, J.; Hoigné, J.: J. Phys. Chem., 88, 2560 
(1984)

9 ) Tomiyasu, H.; Fukutomi, H.; Gordon, G.: Inorg. Chem., 24, 2962 (1985)

10) Ku, Y.; Su, W.; Shen, Y.: Ind. Eng. Chem. Res., 35, 3369 (1996)

11) Somiya, I.: “Ozone Handbook” , Nippon Ozone Kyokai Ed., Sanyu Shobou, Yokohama, p.52 (2004)

12) Gottaschalk, C.; Libra, A. J.; Saupe, A.: “Ozonation of Water and Waste Water”, Wiley-VCH Verlag, Weinheim, p.18 (2010)

13) Haag, W. R.; Yao, C. C. D.: Environ. Sci. Tech., 26, 1005 (1992)

14) Buxton, G. V.; Greenstock C. L.; Helman, W. P.; Ross, A. B.: J. Phys. Chem. Ref. Data., 17, 513 (1988)

15) Rosala, R.; Rodríguez, A.; Perdigón-Melón, A. J.; Mezcua, M.; Hernando, D. M.; Letón, P.; García-Calvo, E.; Agüera, A.; Fernández-Alba, R. A.: Water Res., 42, 3719 (2008)

16) Ormad, M. P.; Miguel, N.; Claver, A.; Matesanz, J. M.; Ovelleiro, J. L.: Chemosphere, 71, 97 (2008)

17) Tanimoto, Y.: “Gomu Kogyo Binran (4th ed.)” , Nippon Gomu Kyokai Ed., Nippon Gomu Kyokai, Tokyo, p.307 (1994)

18) Miwa, S.; Kikuchi, T.; Ohtake, Y.; Tanaka, K.: Nippon Gomu Kyokaishi, 83, 324 (2010)

19) Miwa, S.; Kikuchi, T.; Ohtake, Y.; Tanaka, K.: Polym. Degrad. Stab., 96, 1503 (2011)

20) Miwa, S.; Kondo, H.; Ontsuka, H.; Ohtake, Y.: Nippon Gomu Kyokaishi, 81, 14 (2008)

21) Tokuhira, K.: “Fusso Kagaku Nyumon 2010-Kiso to Ouyou no Saizensen” , Nippon Gakujutsu Shinkokai Fusso kagaku Dai 155 Iinkai Ed., Sankyo Shuppan, Tokyo, Chapter 6 (2010)

22) Isbester, K. P.; Brandt, L. J.; Kestner, A. T.; Munson, J. E.: Macromolecules, 31, 8192 (1998)

23) Ohtake, Y.; Furukawa, M.: "Zairyo Trouble Chousa File” , Nikkan Kogyo Shinbunsha, Tokyo, p.72 (1999)

24) Hertz, H. J.: Reine. Angew. Mathematik., 92, 156 (1882)

25) Sneddon, I. N.: Int. J. Eng. Sci., 3, 47 (1965)

26) Kobayashi, M.; Tashiro, K.; Tadokoro, H.: Macromolecules, 8, 158
(1975)

27) Banik, I.; Dutta, K. S.; Chaki, K. T.; Bhowmick, K. A.: Polymer, 40, 447 (1999)

28) Mitra, S.; Ghanbari-Siahkali, A.; Kingshott, P.; Almdal, K.; Rehmeier, K. H.; Christensen, G. A.: Polym. Degrad. Stab., 83, 195 (2004)

29) Lin, H. C.: Polymer, 45, 7911 (2004)

30) Fukumori, K.: “Shinban Gomu Gijutsu no Kiso” , Nippon Gomu Kyokai Ed., Nippon Gomu Kyokai, Tokyo, p.41 (2002)

\section{日本語表記参考文献}

1 ）宗宮功：オゾンハンドブック, 特定非営利活動法人日本オゾン 協会オゾンハンドブック編集委員会編，サンユー書房，横浜，1 章 (2004)

2 ）西村喜之，金谷隆文，大久保典昭，岡田和久，花田圭司：日本 食品工学会誌，2，103（2001）

3 ）杉光英俊：オゾンの基礎と応用, 光琳社, 東京, 9章 (1996)

11）宗宮功：オゾンハンドブック，特定非営利活動法人日本オゾン 協会オゾンハンドブック編集委員会編, サンユー書房, 横浜, p.52 (2004)

17）谷本嘉雄：ゴム工業便覧 (第 4 版), 日本ゴム協会編, 日本ゴム 協会，東京，p.307（1994）

18）三輪怜史，菊地貴子，大武義人，田中敬二：日本ゴム協会誌， 83, 324 (2010)

20）三輪怜史, 近藤寛朗, 隠塚裕之, 大武義人：日本ゴム協会誌, 81, 14 (2008)

21）徳平勝貞：フッ素化学入門 2010-基礎と応用の最前線，日本学術 振興会・フッ素化学第 155 委員会編, 三共出版, 東京, 6 章 (2010)

23）大武義人，古川睦久：材料トラブル調査ファイル，日刊工業新 聞社，東京，p.72（1999）

30）福森健三：新版ゴム技術の基礎，日本ゴム協会編，日本ゴム協 会，東京，p.43（2002） 